\title{
Academic Experience in another Country: Reflections on the University Reality of Brazil and United States
}

\section{Rigo Guerra L and Stein Backes D* \\ Centro Universitário Franciscano/RS, Brazil}

*Corresponding author: Dirce Stein Backes, Centro Universitário Franciscano, Nursing course of the Centro Universitário Franciscano/RS, Brazil, Email: backesdirce@unifra.br

\section{Short Communication}

Volume 2 Issue 1

Received Date: March 13, 2018

Published Date: April 16, 2018

DOI: $10.23880 /$ whsj-16000111

\section{Abstract}

The objective in this study is to report the perceptions about the university realities of Brazil and the United States during the academic experience in an American nursing school. It is a report of an academic experience that was realized in an American University in the United States during the exchange program known as Science without Borders, funded by the Brazilian government. The US institution of choice for the exchange program was the Milwaukee School of Engineering (MSOE) - School of Nursing. The contact with a differentiated academic reality, with well-equipped university environments and with trained professors, the international academic mobility provides the contact with people from different parts of the world. The academic experience in another country is very important, not only for those who live this experience, but also for the institution that sends the student. The student, when they return to their country, they bring with them an incalculable baggage of learning. The student can share with their academic community everything they have experienced and, planning changes to their own institution, too.

Keywords: Scholarships; Technology; Experience

\section{Introduction}

Do you know where the best universities in the world are located? Certainly, several of them are established in the United States [1]. The answer to this, presumably, is due to the fact that this country belongs to the select group of countries that make up the "first world". They are solid economies that make high investments so that they continue to grow and consolidate more and more as a world power. Therefore, an adequate professional training, through a qualified education, generates immeasurable fruits for a nation. In this way, universities play an important role in developing a country by preparing professionals capable of meeting current demands.

The American universities, recognized worldwide by the excellence of their academic programs, attract students from all over the world. There are numerous research, undergraduate and postgraduate scholarships that have been offered by them every year. The governments of countries that send students to the United States fund many scholarships. Also, these countries expect that the sent student 


\section{Women's Health Science Journal}

return to home and then, contribute to their scientific and technological development.

The academic experience in a university outside of Brazil means a great contribution for the education of students. A new world is discovered and new aspirations are idealized. Experiencing the daily life in a university, attending classes, attending events, submitting papers and attending research groups enables the student to have an extremely aggregating experience with regard to their training. Inevitably, comparisons between American institutions ane the Brazilian ones are made.

However, there is no intention to disparage or diminish the Brazilian institution, but to carry out an analysis of our weaknesses and potentialities, in order to aim for something greater. Thus, we need to analyze, re-thought and even compare from physical space to the pedagogical model of universities, in order to reach a deeper and accurate evaluation of our current situation. In view of this, my objective in this study is to report the perceptions about the university realities of Brazil and the United States during the academic experience in an American nursing school.

\section{Methodology}

It is a report of an academic experience that in an American University in the United States during my exchange program known as Science without Borders [2], funded by the Brazilian government. The program aims to expand and internationalize science and technology, innovation and Brazilian competitiveness through international exchange programs and mobility. The program made it possible by allowing me to immerse in a North American university by allowing me to attend several disciplines related to the Nursing course, as well as to participate in relevant events for my academic education. The total duration of the program was 15 months, beginning in July 2014 and ending in November 2015.

The US institution of choice for my exchange program was the Milwaukee School of Engineering (MSOE) - School of Nursing. According to the university's website [3], MSOE - School of Nursing aims to train technically competent and socially responsible nurses. The advanced simulation technologies prepare students to perform, afterwards, in real patients. Students are trained with the necessary knowledge and skills to care for individuals, families and communities in complex health settings. All the academic experiences mentioned in this report are related to my experience on that university.

Thus, it is justified itself to choice for the experience report, because it is a tool of the descriptive research that presents a reflection on an action or a set of actions that approach a situation experienced in the professional scope of interest for the scientific community [4].

Lastly, the baccalaureate curriculum both in Brazil as in United States is designed to prepare students for work within the growing and changing health-care environment. In addition, nurses are expected to develop critical-thinking and communication skills, as well as to provide a health care based on ethical standards. Also, in a university or college setting, the first two years include classes in the humanities, social sciences, basic sciences, business, psychology, technology, sociology, ethics, and nutrition $[5,6]$.

\section{Reporting the Experience}

The dream of entering a university is something grandiose itself and becomes even more significant when lived in another country. Those who invest in this opportunity and leave for a real immersion in another country can only expect a great return in the form of maturation and growth, not only in a professional matter but also in all the dimensions of their existence.

In addition to the contact with a differentiated academic reality, with well-equipped university environments and with trained professors, the international academic mobility provides the contact with people from different parts of the world. Therefore, it is a great opportunity. Interacting with people from many countries and cultures adds much to the training. Internationally renowned institutions bring people from all over the world with one common goal: the exchange of knowledge. During my experience, the real feeling was to be everywhere in the world at the same time. The East and the West were closer than ever. Geographical limits were practically nonexistent. Anyone could learn a lot in a simple "group conversation".

The discussions in the classroom have always been very rich. The professors raised questions and were always very interested in hearing the experiences that we have had in our countries. The discussions often revolved around the Brazilian Health System (SUS). We shared our experiences and told them how the Brazilian Health System (SUS) runs in our country. To exemplify one of 


\section{Women's Health Science Journal}

these discussions, I remember the day we talked to a professor about the high rates of cesarean births in Brazil. In Brazil, the rate of cesarean sections increased from $15.6 \%$ in 1970 to $31.0 \%$ in 1980 (3) and from $31.6 \%$ in 1986 to $36.4 \%$ in 1996 [7]. The numbers we presented surprised the professor. In addition, we tried to explain all the circumstances, beliefs and medical hegemony that revolve around this situation.

At another time, during History and Theories of Professional Nursing Practice classes, we had the opportunity to learn more about the history of nursing in the United States and the great theories that have cemented the profession as a science over the years. Moreover, as one of the required activities by the discipline, we had to prepare a seminar on nursing theories. Each student was assigned to present to the class a theorist with their own theory. Then, the group of Brazilian students who were taking this course prepared a presentation about the Brazilian Wanda de Aguiar Horta and her theory about the basic human needs. This moment was an opportunity to introduce one of the Brazilian theorists to the class. Basically, this theory is based on the laws of balance, adaptation and holism. Basic human needs are states of tensions, conscious or unconscious, resulting from the homeodynamic imbalances of vital phenomena [8]. The systematization of nursing care in Brazil is developed by bringing concepts from American nursing theorists as well as the Brazilian ones. When the Horta's theory is cited, some factors as individuality, age, sex culture, schooling, and physical environment are used to think the nursing assistance.

Other aspects of the academic culture of the United States have also drawn attention. The curricular structure itself, divided into quarters, allowed for greater dynamics between the disciplines. Students could study more topics in a greater number of courses. On the other hand, the almost three months of classes seemed not to be enough and, often, the students were overwhelmed with so many activities, tests and material to be studied.

It was also observed that the students had greater independence with regard to the organization of their own academic life. The professor, on many occasions, had a supporting role in the learning process. In addition, the professor played the role of facilitator, unlike what happens in Brazil, where the student is still very dependent on the professors to help them in the process of building their own knowledge. We still have a culture of not preparing ourselves before a class. We do not read about the subject that we would be discussed before we go to class. We deal with and limit ourselves only to what the professor teaches in the classroom and, hardly, we go further. Consequently, we had to adapt ourselves to this model of education. Otherwise, many of the classes would not have been really enjoyed because the professor just would get into the classroom and made a brief outline about the chapters of the book that everyone should have read at home.

\section{Final Considerations}

The academic experience in another country is very important, not only for those who live this experience, but also for the institution that sends the student. The student, when they return to their country, they bring with them an incalculable baggage of learning. The student can share with their academic community everything they have experienced and, planning changes to their own institution, too.

It is always important to emphasize that the student who carries out part of their graduation in another country is representing their nation and university. Therefore, it is advised that all who seek to live this experience should commit them to everything they do and pursue their dream until they may reach it. In addition, focus and determination are important to overcome the difficulties encountered when living away from home, family and friends. Finally, I would give the following advice to future exchange students: enjoy every moment as much as possible, because it consists of a great experience that will change the way they see the world, making them more mature to face the challenges in life.

\section{References}

1. Strauss K (2017) The World's Top Universities in 2017.

2. Science without borders. The program.

3. Milwaukee School of Engineering (MSOE) School of Nursing. Undergraduate degrees.

4. Cavalcante BLL, Lima UTS (2012) Relato de experiência de uma estudante de Enfermagem em um consultório especializado em tratamento de feridas. J Nurs Health, Pelotas (RS) 2(1): 94-103. 


\section{Women's Health Science Journal}

5. American Association of Colleges of Nursing. Baccalaureate Education.

6. National Curricular Guidelines of the Undergraduate Nursing Course (Brazil) (2001). Resolução CNE/CES № 3, de 7 denovembro de.
7. Bemfam (Bem-Estar Familiar no Brasil) (1997) Pesquisa Nacional sobre Demografia e Saúde 1996. Rio de Janeiro: Bemfam.

8. Horta WA (2012). Processo de enfermagem. Rio de Janeiro: Guanabara Koogan.

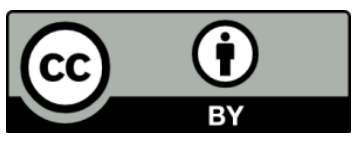

